\title{
Cohesion Policy in Poland and in the Czech Republic - Challenges and Prospects
}

\begin{abstract}
The aim of the cohesion policy is to accelerate the socio-economic development of Member States and their regions. Poland as well as its closest neighbour, the Czech Republic, have benefited from structural funds and the Cohesion Fund. The effects of provided aid have already become apparent but they differ given the scale of problems, including regional issues existing in these countries, and the amount of funds allocated. The aim of the article is to present the directions and the effects of the implementation of the cohesion policy in Poland and the Czech Republic with particular focus on the financial perspective of 2007-2013. The results of the evaluation of programmes for the years 2007-2013 show that EU funds are mostly spent on transport infrastructure. However, the support of entrepreneurship and innovation and human capital should be an important objective in the current programming perspective in order to transform and modernise the structure of economies.
\end{abstract}

Key words: EU Cohesion Policy, Regional Disparities, Cohesion, EU Structural Funds, Cohesion Fund

\section{Introduction}

The aim of the cohesion policy is to accelerate the socio-economic development of Member States and their regions. The greatest financial resources are allocated to the poorest EU countries, including Poland. In recent years, this aid has been of significant importance in Central and Eastern European countries, especially considering the amount of funds

* Małgorzata Dziembała - University of Economics in Katowice, e-mail: malgorzata.dziembala@ue.katowice.pl, ORCID: 0000-0002-8992-8627. 
provided to them. EU funds are aimed at reducing/mitigating the existing problems, accelerating their economic development and modernisation of their economies. Poland as well as its closest neighbour, the Czech Republic, have benefited from structural funds and the Cohesion Fund since 2004. The effects of provided aid have already become apparent but they differ given the scale of problems, including regional issues existing in these countries, and the amount of funds allocated. Therefore, it is useful to draw attention to the use of cohesion policy funds in those two EU countries, all the more so as it is possible to make some initial assessments already.

The aim of the article is to present the directions and the effects of the implementation of the cohesion policy in Poland and the Czech Republic with particular focus on the financial perspective of 2007-2013. The effects of funds allocated to these countries are said to be significant in terms of various aspects. It seems, however, that the EU funds should be to a greater extent aimed at the investments which contribute to the ongoing modernization of economies, especially in Poland. The following research methods have been used in the article: critical analysis of source literature and analysis of statistical data.

\section{Socio-economic Development of Poland and the Czech Republic}

The issue of reducing interregional disparities and raising the level of socio-economic development is the subject of detailed deliberations in the countries of Central and Eastern Europe, including Poland, which has been availing of EU assistance under the cohesion policy since 2004. Therefore, the discussions are underway regarding the use of these funds, their importance for the stimulation of development and structural changes in the new EU member states, also considering the scale and problems existing in these countries. ${ }^{1}$ The socio-economic development in these two countries was subject to changes in the EU membership conditions. Their starting position was different though - in 2004, GDP per capita in the Czech Republic reached $78 \%$ of the average GDP per capita in EU-28 while in Poland it

1 See: J. Kudełko, A. Prusek, K. Zieliński, Europejska polityka spójności oraz jej efekty w Polsce (European cohesion policy and its effects in Poland), Wydawnictwo Uniwersytetu Ekonomicznego w Krakowie, Krakowie, Kraków 2011; D. Murzyn, Polityka spójności Unii Europejskiej a proces zmniejszania dysproporcji w rozwoju gospodarczym Polski (EU cohesion policy and the proces in the economic development of Poland), Wydawnictwo C.H. Beck, Warszawa 2010; Polityka spójności w okresie 2014-2020 a rozwój regionów Europy (Cohesion policy in 2014-2020 and development of regions of Europe), eds. E. Pancer-Cybulska, E. Szostak, Prace Naukowe Uniwersytetu Ekonomicznego we Wrocławiu, no. 227, Wrocław 2011. 
reached $50 \%$ of the EU-28 average. ${ }^{2}$ However, the socio-economic growth rate in terms of GDP/per capita, varies both among and within the Central and Eastern European countries. Those two countries differ also in terms of GDP per capita (figure 1, figure 2). Nevertheless, the investments partly covered by the EU funds were the main factor accelerating the growth in the Czech Republic starting from 2013, whereas from 2016, when public investments were reduced, private investments have become an important factor accelerating economic growth, enhanced at the same time by household consumption. ${ }^{3}$ Strong economic growth has also been recorded in Poland in 2010-2016. ${ }^{4}$

Individual regions of the above-mentioned countries do not develop evenly as evidenced by their inter-regional disparities shown in Table 1. While the increase of GDP per capita is observed in the Czech Republic, there is a low convergence in living standards as compared to OECD countries. ${ }^{5}$

While the country-level indices in the Czech Republic are relatively low in terms of income inequalities and poverty rate as compared to their respective values in the OECD, such variations are visible on a regional basis. The highest variations are observed in Prague, then in the Northwest and Central Moravia region in terms of income inequalities and in Northwest and Moravia-Silesia in terms of poverty rate, while the lowest occur in Prague - which is due to many factors. ${ }^{6}$

If one pays attention to the situation of the regions in the Czech Republic, which currently number 8 (NUTS 2 regions), large disparities between Prague and other regions of the country may be observed. Prague as the capital city is growing rapidly. It has been included in the cohesion policy objective of Regional Competitiveness and Employment in the years 2007-2013, given the high level of GDP per capita. On the other hand, the other regions have been included in the objective of Convergence, as their GDP per capita has not exceeded $75 \%$ of the average GDP per capita in the EU. ${ }^{7}$ However, considering the interregional discrepancies in the Czech Republic, their

2 https://ec.europa.eu/eurostat/data/database (15.10.2018).

3 OECD Economy Surveys: Czech Republic 2018, OECD Publishing, Paris, https://doi.org/10.1787/eco_surveys-cze-2018-en , p. 20.

4 OECD Economic Surveys Poland, March 2018, OECD Publishing, Paris 2018, p. 10. http://dx.doi.org/10.1787/eco surveys-pol-2018-en.

5 OECD Economy Surveys: Czech Republic 2018..., op. cit., pp. 9, 17-18.

${ }^{6}$ OECD Economy Surveys: Czech Republic 2018..., op. cit., p. 19; Regions and cities at a glance 2018 - Czech Republic, OECD, http://www.oecd.org/cfe/CZECH-REPUBLIC-Regions-and-Cities-2018.pdf (3.10.2018).

7 Tasks 3. Country Report Czech Republic, ex post evaluation of Cohesion Policy programmes 2007-2013, focusing on the European Regional Development Fund (ERDF) and the Cohesion Fund (CF), WP1: Synthesis report, Applica, Ismeri Europa and Cambridge Economic Associates, Publications Office of the European Union, Luxembourg 2016, p. 11. 
increase is observed if GDP per capita in the years 2000-2016 is taken into account. For the richest Prague region, the GDP per capita growth by $55 \%$ was recorded, while in the poorest region - the Northwest - it was lower by 18 percentage points. However, in this analysed period, the growth of disparities is observed until 2008, followed by the period of stabilisation, and then there is an increase again starting from 2014. The highest growth rate of productivity is characteristic for the region of Moravia-Silesia $(2.5 \%$ per annum), then Prague, while the lowest is recorded for Northwest (1.7\% per annum) in 2000-2016. ${ }^{8}$

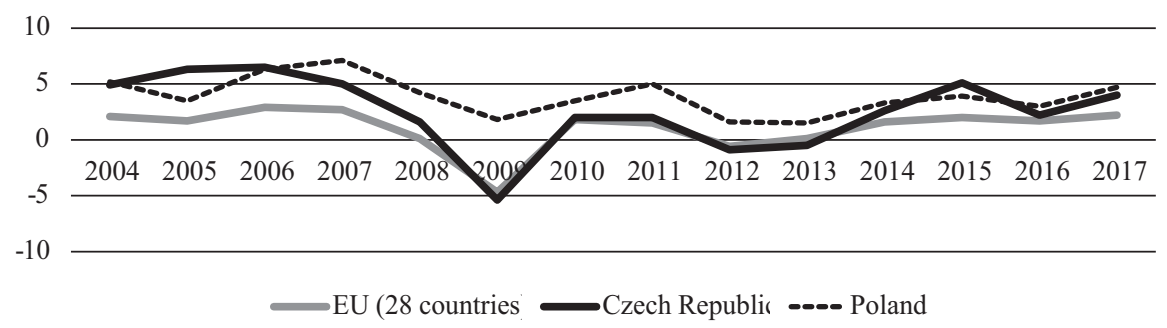

Fig. 1. Changes in GDP per capita, previous year $=100$

Source: prepared based on Eurostat data: https://ec.europa.eu/eurostat/data/database (2.09.2018).

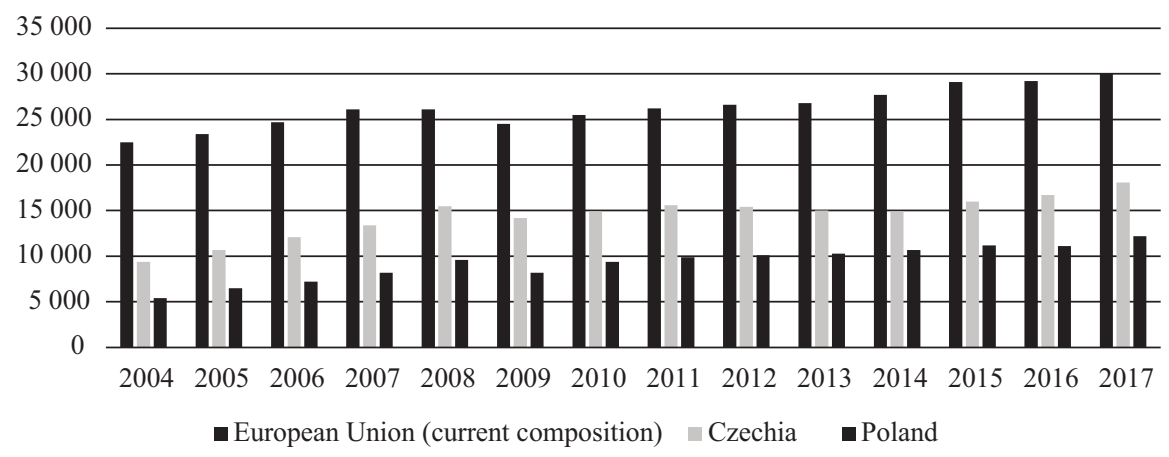

Fig. 2. GDP per capita in the EU, Czechia and Poland, in euro

Source: prepared based on Eurostat data: https://ec.europa.eu/eurostat/data/database (18.10.2018).

Also in Poland there is a strong economic growth, which is accompanied by catching up in the scope of living standards as compared to OECD countries. In Poland, there is a reduction in inequality in terms of poverty and income inequality, and the poverty indicator oscillates around the

\footnotetext{
8 See also: Regions and cities at a glance 2018 - Czech Republic...
} 
average EU value. ${ }^{9}$ As far as Poland is concerned, this country has joined the Convergence objective for the years 2007-2013 due to the low level of regional development, as the poorest regions are those located in the eastern part of the country. At the same time, the existing differences persist, which is a result of historical conditions, the existing division between urban and rural areas, restructuring processes occurring at different rates in the regions in traditional sectors and other factors. ${ }^{10}$

Taking the OECD data on regional disparities into account, Poland is ranked 13 th among the OECD countries; considering disparities between $20 \%$ of the richest regions and $20 \%$ of the poorest ones in terms of GDP per capita, they increased by 5\% in the years 2008-2013. However, in terms of differences in the unemployment rate, Poland is placed 16th among the OECD countries. Positive changes in the Polish regions include increased productivity, which is characterised by high dynamics. ${ }^{11}$ On the other hand, given the regional inequalities between $10 \%$ of the richest regions and $10 \%$ of the poorest regions, in Poland in 2016 they reached one of the highest levels among OECD countries (ranked 4th). However, in terms of productivity growth - the highest increase was recorded in the Wielkopolskie Voivodship - 4.5\% in 2000-2016, and the lowest in the Swiętokrzyskie Voivodship (1.2\% on an annual average). ${ }^{12}$

At present, the GDP per capita in the Czech Republic amounts to 88\% of the EU average (2016), and in Poland the GDP per capita is definitely lower, representing $68 \%$ of the EU average in 2016 (in PPS). On the other hand, considering the currently existing interregional variations, in the Czech Republic the ratio of the richest region (Praha) to the poorest region (Severozápad) in terms of GDP per capita was 2.9:1. In that poorest Czech region, GDP per capita amounted to $63 \%$ of the EU average, in other Czech regions it was above $70 \%$ of the average EU GDP in 2016. In Poland, the richest region was the Mazowieckie Voivodship (109\% of the average GDP per capita in EU), and the poorest one was the Lubelskie Voivodship with $47 \%$ of the average EU GDP per capita, which represents

\footnotetext{
9 OECD Economic Surveys Poland, March 2018..., op. cit., pp. 10, 14.

10 Tasks 3. Country Report Poland, ex post evaluation of Cohesion Policy programmes 2007-2013, focusing on the European Regional Development Fund (ERDF) and the Cohesion Fund (CF), WP1: Synthesis report, Applica, Ismeri Europa and Cambridge Economic Associates, Publications Office of the European Union, Luxembourg 2016, pp. 9, 11.

11 Country notes: Poland, OECD Regional Outlook 2016, https://www.oecd.org/cfe/ regional-policy/regional-outlook-2016-poland.pdf (27.09.2018).

12 Regions and cities at a glance 2018 - Poland, OECD, http://www.oecd.org/cfe/ POLAND-Regions-and-Cities-2018.pdf (19.10.2018).
} 
the ratio 2.3:1. ${ }^{13}$ An important problem in Poland is the low development of its regions, as the GDP per capita in 5 Polish voivodships: Lubelskie, Podkarpackie, Świętokrzyskie, Podlaskie and Warmińsko-Mazurskie did not exceed $50 \%$ of EU GDP per capita. ${ }^{14}$

Table 1. Interregional disparities in Poland and the Czech Republic in view of the selected indicators

\begin{tabular}{|c|c|c|c|c|c|c|c|}
\hline \multirow[b]{2}{*}{ Indicator } & \multicolumn{3}{|c|}{ Czech Republic } & \multicolumn{3}{|c|}{ Poland } & \multirow[b]{2}{*}{$\begin{array}{l}\text { OECD } \\
\text { avg. }\end{array}$} \\
\hline & Min & Max & $\begin{array}{l}\text { Country } \\
\text { average }\end{array}$ & Min & $\operatorname{Max}$ & $\begin{array}{l}\text { Country } \\
\text { average }\end{array}$ & \\
\hline $\begin{array}{l}\text { GDP per } \\
\text { worker (2013) }\end{array}$ & 48,157 & 78,211 & 56,516 & 35,493 & 78,130 & 55368 & 74,520 \\
\hline $\begin{array}{l}\text { R\&D expendi- } \\
\text { ture as a } \% \text { of } \\
\text { GDP }(2013)\end{array}$ & 0.36 & 2.86 & 1.91 & 0.23 & 1.56 & 0.87 & 2.4 \\
\hline $\begin{array}{l}\text { Share of labour } \\
\text { forces with ter- } \\
\text { tiary education }\end{array}$ & 15.1 & 23.7 & 22.2 & 23.8 & 40.6 & 31 & 32.3 \\
\hline $\begin{array}{l}\text { Disposable } \\
\text { household in- } \\
\text { come per capita }\end{array}$ & 10,876 & 15,968 & 12,353 & 16,857 & 22,807 & 19,710 & 34,866 \\
\hline $\begin{array}{l}\text { Share of work- } \\
\text { forces with only } \\
\text { primary educa- } \\
\text { tion }\end{array}$ & 2.3 & 9.8 & 5 & 4.1 & 11.1 & 6,6 & 25.2 \\
\hline $\begin{array}{l}\text { Gender gap in } \\
\text { participation } \\
\text { rate }\end{array}$ & -14 & -17.2 & -16 & -11.4 & -16.4 & $-13,8$ & -15.9 \\
\hline
\end{tabular}

^ for Poland - 2011, for Czechia - 2013

Source: The summary based on: Country notes: Country notes: Czech Republic, OECD Regional Outlook 2016: Productive Regions for Inclusive Societies, OECD 2016, http://www.oecd.org/cfe/regional-policy/regional-outlook-2016-czech-republic.pdf (27.09.2018); Country notes: Poland, OECD Regional Outlook 2016, https://www.oecd. org/cfe/regional-policy/regional-outlook-2016-poland.pdf (27.09.2018).

Other dimensions of variation, covering many aspects of well-being are presented with respect to the regions of Poland and the Czech Republic are presented in Table 2.

13 Eurostat news release 33/2018, 28 February 2018, Regional GDP per capita ranged from $29 \%$ to $611 \%$ of the EU average in 2016, https://ec.europa.eu/eurostat/ documents/2995521/8700651/1-28022018-BP-EN/15f5fd90-ce8b-4927-9a3b-07dc255dc42a (27.09.2018).

14 See data in: Eurostat news release 33/2018..., op. cit. 


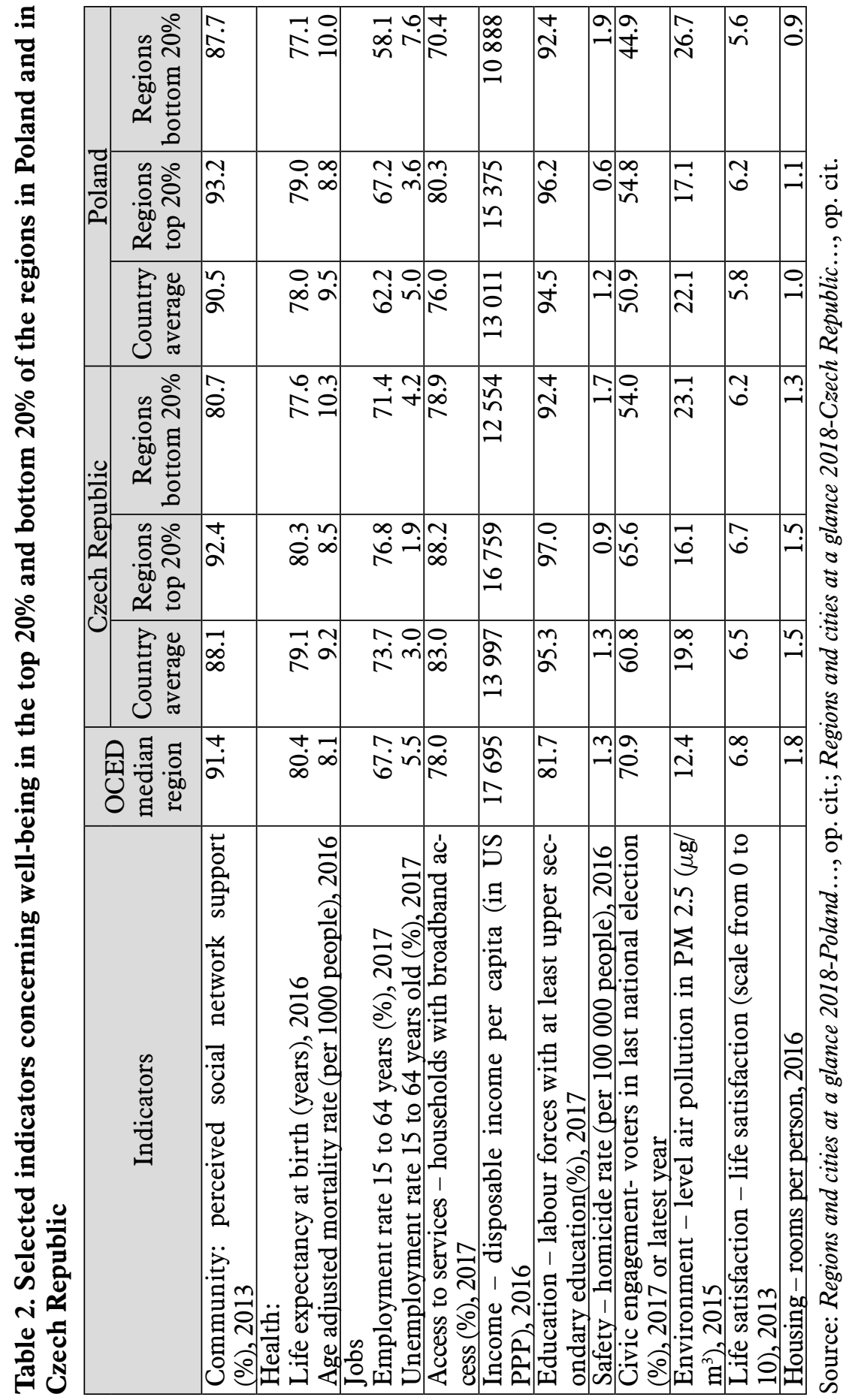




\section{Directions and Effects of Using EU Funds in Poland and the Czech Republic in the Programming Period 2007-2013}

When Poland and the Czech Republic joined the EU, they became the beneficiaries of EU funds. The amount of funds allocated to these countries in the years 2004-2006 was not significant, also due to the short period of funding in that financial perspective. It was not until the next financial perspective 2007-2013 that the amount of funds and, therefore, the scale of the impact of EU aid was and should have been important.

It is also the result of the significant share of EU funds in the total expenditures incurred by the public sector in those countries, the share of which amounted to approx. $41 \%$ in the case of Poland, and $34 \%$ in the case of the Czech Republic in 2007-2013. Those funds became very important during the economic and financial crisis because they stimulated the demand due to the investments being co-financed from those financial resources $^{15}$ (Fig. 2).

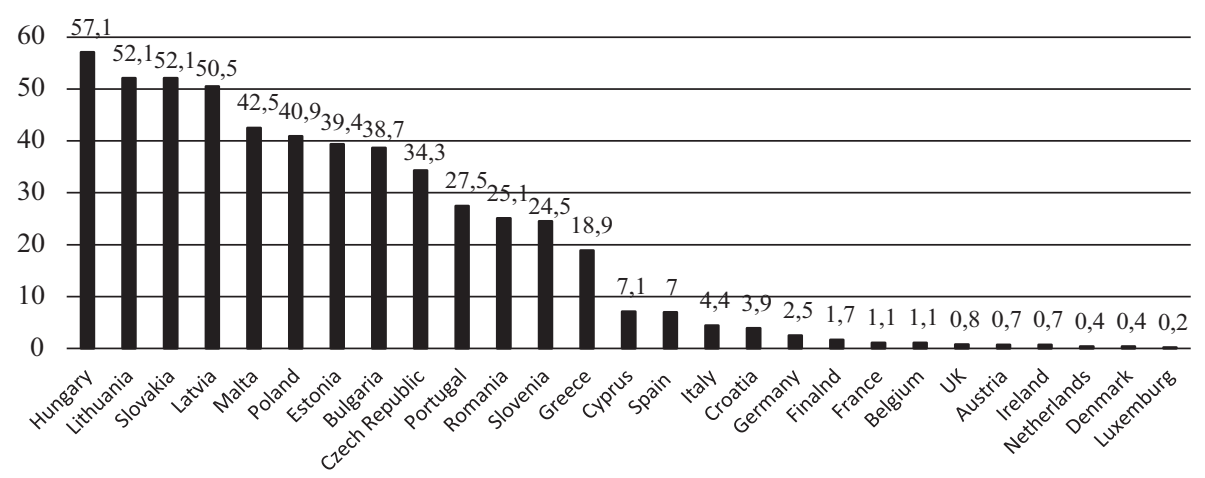

Fig. 2. Cohesion policy funds as \% of government capital expenditure in the EU Member States in the years 2007-2013

Source: Cohesion policy supporting growth and jobs Czech Republic, http://ec.europa. eu/regional_policy/sources/docgener/evaluation/pdf/expost2013/wp1_cz_factsheet_ en.pdf (27.09.2018).

EU funds are spent on the priorities set out in the strategic documents of individual countries, and at the same time contribute to the pursuit of the objectives of the cohesion policy.

The priorities supported from the EU funds in 2007-2013 perspectives are shown in Table 3.As the presented data show, a broad set of

15 The impact of cohesion policy 2007-2013: in Poland, Visegrad Group Countries and partner states, Imapp, Warsaw 2017, p. 5. 
priorities was formulated in the analysed period in Poland, aimed at, among other things, support for infrastructure development, improvement of the competitiveness of regions, development of human capital and innovation of enterprises, which was reflected in the appropriate operational programs.

Table 3. EU funds spending objectives/priorities in Poland and in the Czech Republic in the years 2007-2013

\begin{tabular}{|c|c|}
\hline Country & Objectives in the years $2007-2013$ and priorities \\
\hline Czech Republic & $\begin{array}{l}\text { Strategic objectives and priorities stipulated in the National } \\
\text { Strategic Reference Framework: } \\
\text { 1. Competitive Czech economy - competitive business sector } \\
\text { support of R\&D for innovation, development of sustain- } \\
\text { able travel and tourism sector and utilization of the poten- } \\
\text { tial offered by cultural heritage. } \\
\text { 2. Open flexible and cohesive society - education, increas- } \\
\text { ing employment and employability, strengthening social } \\
\text { cohesion, development of information society, smart ad- } \\
\text { ministration. } \\
\text { 3. Attractive environment - protection and improvement of } \\
\text { the quality of the environment, improving accessibility to } \\
\text { transport. } \\
\text { 4. Balanced development of territory - balanced regional de- } \\
\text { velopment, development of urban areas, development of } \\
\text { rural areas, cohesion region of the capital city of Prague, } \\
\text { European Territorial Cooperation. }\end{array}$ \\
\hline Poland & $\begin{array}{l}\text { Horizontal objectives and priorities of the National Strategic } \\
\text { Reference Framework: } \\
\text { 1. Improving the functioning standard of public institutions } \\
\text { and development of partnership mechanisms(enhancing } \\
\text { abilities of public institutions for the efficient and effec- } \\
\text { tive execution of tasks, strengthening partnership mecha- } \\
\text { nism between public administration and the third sector, } \\
\text { supporting the institutions executing the NSRF. } \\
\text { 2. Improving the quality of human capital and enhancing so- } \\
\text { cial cohesion (improving educational standard of the soci- } \\
\text { ety and improving education level, pursuing active policy } \\
\text { of the labour market, establishing conditions favourable } \\
\text { to entrepreneurship, counteracting poverty and prevent- } \\
\text { ing social exclusion, improving health potential of human } \\
\text { capital). }\end{array}$ \\
\hline
\end{tabular}




\begin{tabular}{|c|c|}
\hline Poland & $\begin{array}{l}\text { 3. Establishment and modernisation of technical and social } \\
\text { infrastructure crucial for better competitiveness of Poland } \\
\text { (increasing the share of public transport in public services, } \\
\text { assuring and developing environment protection infra- } \\
\text { structure, diversifying energy sources and limiting nega- } \\
\text { tive effects of the energy industry on natural environment, } \\
\text { supporting basic social infrastructure). } \\
\text { 4. Improving the competitiveness and innovativeness of en- } \\
\text { terprises, including in particular, the manufacturing sec- } \\
\text { tor with high added value, and development of the service } \\
\text { sector (supporting manufacturing activity that enables } \\
\text { achieving high value added, developing service sector, im- } \\
\text { proving operation of enterprises and their access to exter- } \\
\text { nal financing, developing information society, increasing } \\
\text { investments in research and development and creating in- } \\
\text { novative solutions). } \\
\text { 5. Increasing the competitiveness of Polish regions and pre- } \\
\text { venting their social, economic and spatial marginalisa- } \\
\text { tion-fuller utilisation of the endogenic potential of major } \\
\text { urban centres, hastening development of Eastern Poland } \\
\text { voivodships, counteracting marginalisation and peripher- } \\
\text { alisation of problem area, assisting development of territo- } \\
\text { rial cooperation). } \\
\text { Balancing growth opportunities and supporting structural } \\
\text { changes on rural areas (balancing development opportuni- } \\
\text { ties in rural areas, assisting structural changes). }\end{array}$ \\
\hline
\end{tabular}

Source: as cited in: National Strategic Reference Framework of the Czech Republic 20072013, Fuly 2007, Ministrestvo Pro Mistni Rozwoj, pp. 42-73, http://www.dotaceeu.cz/ getmedia/247dcbb4-bfc3-4ef8-9c43-4e17ec16aead/NSRF_en_170707_bez_zmen_db_fintabulka (19.10.2018); Poland, National Strategic Reference Framework $2 \overline{0} 07-\overline{2} 013$ in supporting growth and jobs, National Cohesion Strategy, Document adopted by the European Commission on $7^{\text {th }}$ May 2007, pp. 51-80, https://www.funduszeeuropejskie.2007-2013.gov.pl/ WstepDoFunduszyEuropejskich/Documents/NSRO_an_20_07.pdf (27.09.2018).

As shown in Table 3, in the documents prepared for the programming period 2007-2013, attention was drawn to a number of diverse priorities reflecting the internal situation of Poland and its problems. Each of the analysed countries adopted its own objectives resulting from the existing conditions. The allocation of EU funds for these two countries for 2007-2013 is presented in Table 4.

In the 2007-2013 financial perspective, the Czech region of Prague has been covered by the Regional Competitiveness and Employment objective and the remaining regions fall within the Convergence objective. 17 operational programs were prepared for that period. ${ }^{16}$ The total

${ }^{16}$ European Cohesion policy in the Czech Republic, European Union..., op. cit. 
allocation granted to Poland amounted to approximately 67 billion euro, distributed through 5 operational programs on a national level and 16 regional programs. At the same time, the operational program with the largest allocation of European funds - ERDF and CF - was Operational Programme (OP) Infrastructure and Environment of nearly EUR 28 billion, and another OP Human Capital with an allocation of about EUR 10 million from ESF. ${ }^{17}$

Table 4. Allocation of EU funds and the size of national co-financing from public sources for Poland and the Czech Republic for the period of 20072013, in EUR billion

\begin{tabular}{|c|c|c|c|c|c|c|c|c|}
\hline \multirow[b]{2}{*}{ Objectives } & \multirow[b]{2}{*}{ Funds } & \multicolumn{3}{|c|}{ Czech Republic } & \multicolumn{4}{|c|}{ Poland } \\
\hline & & EU & $\begin{array}{l}\mathrm{Na}- \\
\text { tional } \\
\text { Public }\end{array}$ & Total & EU & $\begin{array}{c}\text { Na- } \\
\text { tional } \\
\text { Public }\end{array}$ & $\begin{array}{c}\mathrm{Na}- \\
\text { tional } \\
\text { Private }\end{array}$ & Total \\
\hline \multirow{3}{*}{$\begin{array}{l}\text { Objective } \\
\text { Conver- } \\
\text { gence }\end{array}$} & $\mathrm{CF}$ & 8.8 & 1.5 & 10.3 & 22 & 6 & 1.5 & 29.5 \\
\hline & ERDF & 13.4 & 2.3 & 15.8 & 33 & 6 & 1.5 & 40.5 \\
\hline & ESF & 3.5 & 0.6 & 4.2 & 10 & 2 & & 12 \\
\hline $\begin{array}{l}\text { Total: Con- } \\
\text { vergence }\end{array}$ & & 25.8 & & & 65 & & & \\
\hline \multirow[b]{2}{*}{$\begin{array}{l}\text { Objective: } \\
\text { Regional } \\
\text { Competi- } \\
\text { tiveness and } \\
\text { Employ- } \\
\text { ment } \\
\end{array}$} & ERDF & 0.3 & 0.04 & 0.3 & & & & \\
\hline & ESF & 0.2 & 0.02 & 0.2 & & & & \\
\hline Total & & 0.5 & & & & & & \\
\hline $\begin{array}{l}\text { Objective: } \\
\text { European } \\
\text { Territorial } \\
\text { Cooperation }\end{array}$ & ERDF & 0.4 & - & 0.4 & 0.7 & & & 0.7 \\
\hline $\begin{array}{l}\text { Total - all } \\
\text { objectives }\end{array}$ & & 26.7 & 4.6 & 31.3 & 66 & 14 & 3 & 83 \\
\hline
\end{tabular}

^ each of Territorial Cooperation programme includes a minimum of $15 \%$ co-financing from each of the Member states that participate in the programme

ERDF - European Regional Development Fund, ESF-European Social fund, CF- Cohesion Fund.

Source: compilation based on: European Cohesion policy in the Czech Republic, European Union, http://ec.europa.eu/regional_policy/sources/docgener/informat/country2009/cs en.pdf (3.10.2018); European Cohesion policy in Poland, European Union, http://ec.europa.eu/regional_policy/sources/docgener/informat/country2009/ pl_en.pdf (3.10.2018).

\footnotetext{
17 European Cohesion policy in Poland, European Union..., op. cit.
} 
Therefore, what are the effects of investments carried out from funds allocated within the 2007-2013 financial perspective in these countries? Are they conducive to the process of catching up with richer EU countries?

It is estimated that the amount of the additional increase in actual GDP per capita, which was possible thanks to EU funds, amounted to 4 p.p. for Poland and 6.6 p.p. for the Czech Republic in comparison to the baseline scenario, thus making an important contribution to the economic growth (EU Impact MOD model). These funds have also contributed to the convergence in the scope of GDP per capita. According to the European Commission's model Quest III, the GDP growth was higher than in baseline scenarios by 4 p.p. in the case of the Czech Republic, and by 4.3 p.p. in the case of Poland in 2015 thanks to EU funds. At the same time, the importance of EU funds during the second wave of the crisis, i.e. in the years 2012-2013, is emphasised through the intensification of the demand and the reduction of its adverse impact. ${ }^{18}$

Implemented projects co-financed from the EU funds have an influence on employment, contributing to the creation of new jobs. It is estimated that they contributed to the increase in the employment rate, they also resulted in an decrease in the unemployment rate, which was below the EU average in these two countries in 2016. Poland recorded the greatest changes in the labour market among the Visegrad Group countries, taking both higher employment rate and unemployment rate into account. ${ }^{19}$

As it is pointed out, in Poland significant EU funds are aimed at the development of transport infrastructure, and ICT is also supported. In order to increase the impact, it is recommended to improve the quality of these investments in order to increase their influence on innovation and development. ${ }^{20}$ Basic infrastructure investments were carried out in the poorest regions, while it is observed that projects of significant added value were implemented in the more prosperous regions of Poland and the Czech Republic, as demonstrated by the analysis concerning the projects implemented in the 2007-2013 period. ${ }^{21}$ The studies covering the period of 2006-2011 in the Czech Republic show the positive effects of support through the training of employees thanks to the ESF, in the scope of employment. Here, particular attention is paid to the support offered to large

18 The impact of cohesion policy 2007-2013: in Poland..., op. cit., pp. 9-10.

19 Ibidem, pp. 10-13.

20 OECD 2016 after: OECD Economic Surveys: Poland 2018..., op. cit., p. 34.

21 L. Smékalová, P. Janiček, M. Škarka, V. Kozák, Spatial concentration of the cohesion policy projects nationally delimitated intervention areas: the case of the Czech Republic and Poland, "Economics and Sociology", vol. 8, no. 2/2015, pp. 211-226. 
and medium-sized enterprises and its effect in the scope of employment. However, the sustainability of those effects is insufficient. ${ }^{22}$

However, focusing on the basic "hard" transport infrastructure and excessive investment in this area in the less-developed regions may not always be effective in accelerating the economic development of those territorial units and in overcoming their barriers to development, and may even prevent that from happening. Unless other mechanisms for the development of those regions are created, for example in the area of education, transport infrastructure may be necessary in that context..$^{23}$

In Poland, more EU funds (per capita) were directed to less-developed regions in 2004-2011, however, this was not reflected in the faster development of those areas as they developed more slowly than better developed regions. And this may show that the demand effect of using EU funds is stronger, which notably contributes to the improvement of living conditions, and thus their supply effect is much weaker. Absorption of EU funds, when considering NUTS 3 level, was by far the highest in cities where they were concentrated, in the period of 2007-2012. On the other hand, the regions and local units which were granted the highest share of financial resources are the ones which are most developed and have the highest development dynamics. Therefore, so far EU funds are first and foremost important for the improvement in living conditions in Poland. ${ }^{24}$

It should be noted that an external aid, if endogenous conditions allow its use in order to effect structural changes, may be of a pro-development nature. ${ }^{25}$ However, it can also help to replace the priorities and objectives of the regions with those related to the actual acquisition of funds. ${ }^{26}$

\section{Main Intervention Areas Supported by the EU Funds in the 2007-2013 Financial Perspective}

The Visegrad Group countries allocated funds to different intervention areas, but they mostly focused on eliminating the existing deficiencies in infrastructure. The main directions of expenditures include not only

22 O. Potluka, J. Brůha, EU cohesion policy attribution to employment; a case of the Czech Republic, https://ecpr.eu/Filestore/PaperProposal/e13a3696-4251-4f98-8800d72e79c343ba.pdf (19.10.2018).

23 G. Gorzelak, Fakty i mity rozwoju regionalnego (Facts and Myths of Regional Development), „Studia Regionalne i Lokalne”, no. 2(36)/2009, pp. 19-22.

24 G. Gorzelak, Wykorzystanie środków Unii Europejskiej dla rozwoju kraju-wstępne analizy (Utilisation of EU financial resources for the development of country - preliminary analyses), „Studia Regionalne i Lokalne”, no. 3(57)/2014, pp. 5-25.

25 G. Gorzelak, Fakty i mity rozwoju regionalnego..., op. cit., p. 16.

26 Ibidem, pp. 18-19. 
transport, environment and energy but also those aimed at promoting innovation and competitiveness. The allocations made to the intervention area - innovation and competitiveness in the years 2007-2013 represented $16.4 \%$ of the funds allocated to Visegrad Group + 4 (Bulgaria, Romania, Croatia, Slovenia), countries under the cohesion policy in the period 2007-2013, which amounted to EUR 25.8 billion. ${ }^{27}$ The importance of this direction of support resulted from the Lisbon strategy. In Poland, the funds were allocated for the direct support of investments, especially for the development of innovative products and processes, the use of ICT technologies and the support of enterprises. On the other hand, in the Czech Republic, the R\&D support in the field of research projects and $\mathrm{R} \& \mathrm{D}$ public infrastructure was significant.

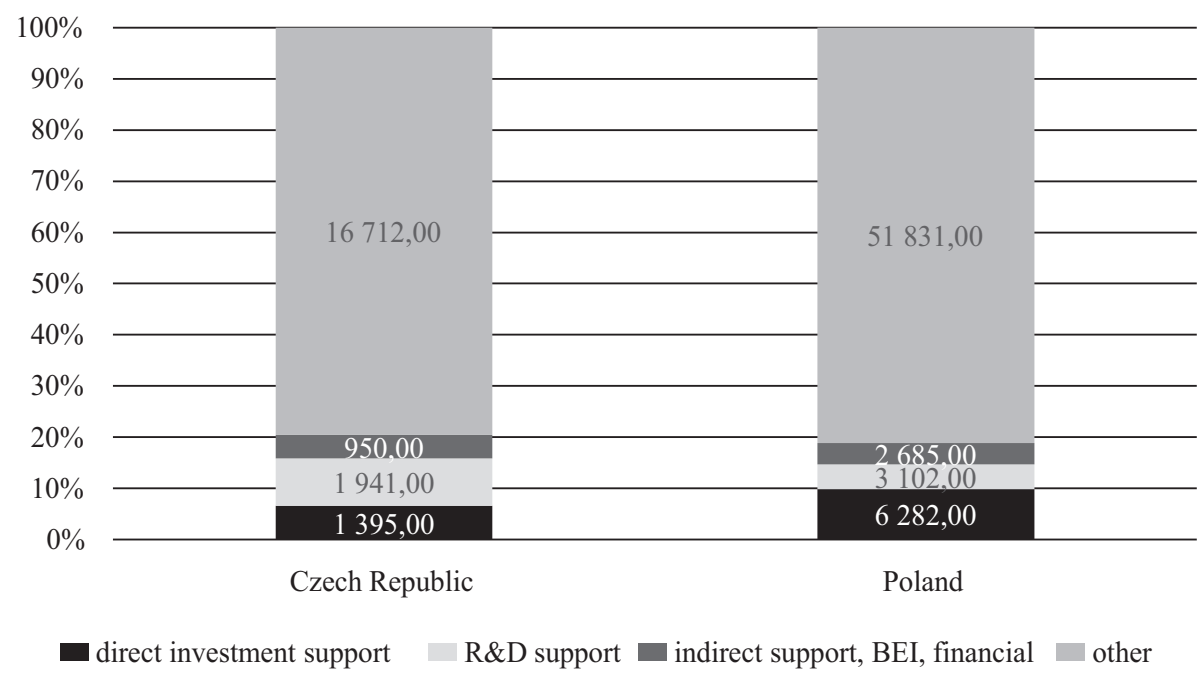

Fig. 3. Expenditures on innovation and competitiveness in the 2007-2013 financial perspective in Poland and in the Czech Republic, in EUR million

Source: The impact of cohesion policy 2007-2013: in Poland..., op. cit., p. 14.

These funds will support expenditures made in relation to $R \& D$, which are still low, considering those incurred by the public and corporate sector.

Under the 2007-2013 financial perspective, a significant amount of EU funds was allocated to transport, representing approx. 30.4\% of cohesion policy funds in the EU, whereas Poland was characterised by the largest percentage, approximately $45 \%$ of total allocation. Funds were mainly allocated to roads and then railways. In terms of the Visegrad Group coun-

\footnotetext{
27 The impact of cohesion policy 2007-2013: in Poland..., op. cit., p. 14.
} 
tries +4 , road projects $(64 \%)$ dominated in the entire group, followed by investments in the field of railway transport (26\%). ${ }^{28}$ In the Czech Republic, on the other hand, ERDF and CF allocation in those areas accounted for $35 \%$ of all available funds, i.e. 7.8 billion, with $47 \%$ of this amount directed to roads and $37 \%$ to railways. ${ }^{29}$

However, the categories of the investments carried out depend on many factors, including natural conditions. ${ }^{30}$ The analysis of directions in transport interventions in these two countries indicates that significant projects in the field of investments in road infrastructure were implemented in Poland $-1,886 \mathrm{~km}$ of new roads were built here as compared to $312 \mathrm{~km}$ in the Czech Republic, new TEN-T roads were constructed $1056 \mathrm{~km}$ in Poland as compared to $111 \mathrm{~km}$ in the Czech Republic, and the condition of roads was improved: 7,216 km in Poland, and 2,018 km in the Czech Republic. In Poland, around 39\% of the national network benefited from these investments, and 31\% in the Czech Republic. ${ }^{31}$ Road investments in Poland accounted for $2 / 3$ of the total investments made in the field of transport from EU funds, which accounted for around half of the public expenditure on infrastructure in Poland. ${ }^{32}$

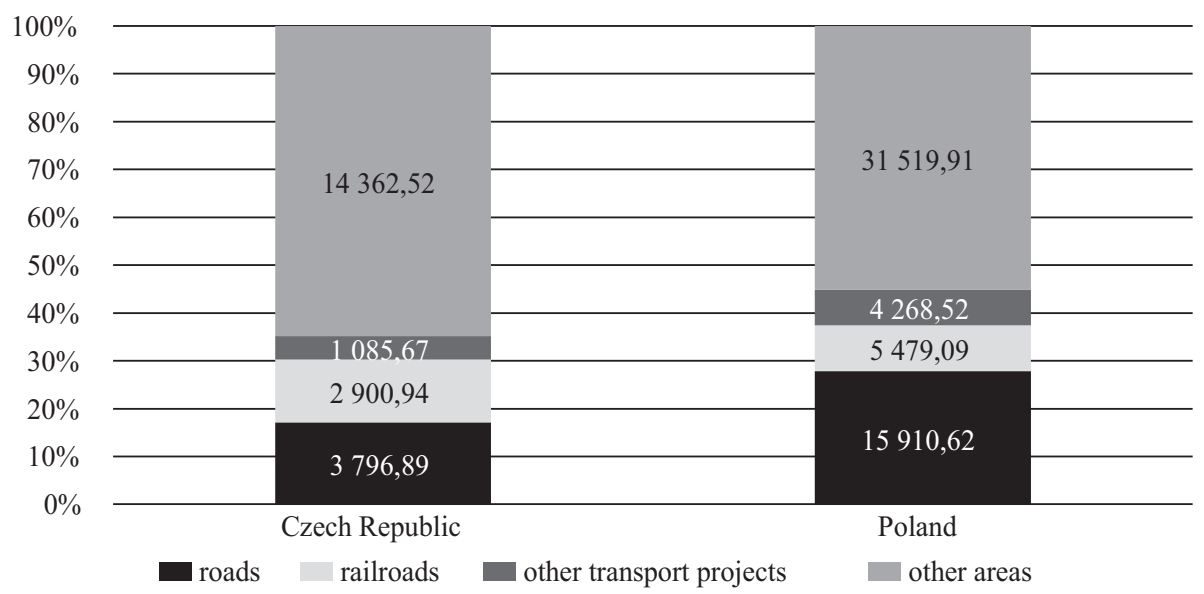

Fig. 4. Amount of EU funds allocated to transport in the financial perspective 2007-2013 in Poland and in the Czech Republic (in EUR million)

Source: The impact of cohesion policy 2007-2013: in Poland..., op. cit., p. 34.

\footnotetext{
28 Ibidem, pp. 34-35.

29 Tasks 3. Country Report Czech Republic..., op. cit., p. 19.

30 The impact of cohesion policy 2007-2013: in Poland..., op. cit., p. 35.

31 The impact of cohesion policy 2007-2013: in Poland..., op. cit., pp. 37-38; Tasks 3. Country Report Poland..., p. 19; Tasks 3. Country Report Czech Republic..., op. cit., p. 19.

32 Tasks 3. Country Report Poland..., op. cit., pp. 18-19.
} 
The benefits arising from the implementation of projects and therefore the effects of interventions in the Visegrad Group countries vary. The objectives to the achievement of which they are supposed to contribute include the stimulation of the development of less-favoured areas and regions. As indicated, the effects of interventions are associated with the creation of additional demand stimuli by spending funds; the implementation of projects is associated with shares of the companies of the Visegrad Group countries and directly with the products of these projects (effects), as well as with the long-term effects of interventions to the achievement of which these funds are supposed to contribute. External effects of interventions made, experienced by the EU-15 countries through indirect export benefits associated with the intensification of demand for imported products in the Visegrad Group countries, and direct export and capital benefits are also of importance (for example, contractors from the EU-15 countries implement projects supported by EU funds. It is shown that approx. 5\% of funds disbursed in Poland return to the EU-15 countries). However, there are also indirect benefits related to the increased demand in Poland for products/services imported as a result of investment supported by EU funds; both direct and indirect funds represent approx. $18.5 \%$ of financial allocations under the EU Cohesion Policy in the years 2004-2008 but due to the distribution of allocated funds, the scale of benefits may change. Moreover, there are long-term external effects for enterprises, entities and communities from the EU-15 countries as well as for institutions. ${ }^{33}$

The directions of distribution of ERDF and CF funds should also be noted. Finally, EUR 57.2 billion were allocated to these two funds in Poland, which represented $2.2 \%$ of GDP and $40.9 \%$ of government capital expenditures, which represented EUR 214 per capita. ${ }^{34}$ However, the allocation made under these two funds for the Czech Republic in that period amounted to EUR 22.1 billion, representing $2 \%$ of GDP and $34 \%$ of

33 Jak państwa UE-15 korzystaja z realizacji polityki spójności w krajach Grupy Wyszehradzkiej? Raport końcowy z badania pt. Ewaluacja ex post i prognoza korzyści uzyskiwanych przez państwa UE-15 w wyniku realizacji polityki spójności w krajach Grupy Wyszehradzkiej (How do EU-15 Member States benefit from the cohesion policy in the V4? Final report from the evaluation: Ex-post evaluation and forecasts of benefits to EU-15 countries as a result of cohesion policy implementation in the V4), IMAPP sp. z 0.o., IBS, Warszawa 2017, pp. 34-35; Ocena korzyści uzyskiwanych przez Państw UE-15 w wyniku realizacji polityki spójności w Polsce. Raport końcowy (Evaluation of benefi ts gained by EU-15 as a result of the implementation of cohesion policy in Poland. Final report), Instytut Badań Strukturalnych 2017.

${ }^{34}$ Tasks 3. Country Report Poland..., op. cit., p. 12. 
capital expenditure. It represented EUR 334.8 in convergence regions and EUR 51.8 per person in the field of competitiveness. ${ }^{35}$

The directions of spending these funds in the years 2007-2013 in the two countries are presented in Table 5. The detailed analysis of the use of these funds shows that investments made in transport in Poland are a priority; innovations, entrepreneurship, business support, and ICT are also among important expenditures. Another group includes the environment, in particular the areas related to the water supply, sewage disposal and waste management. ${ }^{36}$ As it has been already mentioned, the support from the funds in the Czech Republic is provided under two objectives, which results in the diversification of directions of interventions. Under the Regional Competitiveness and Employment objective funds were allocated for the support of enterprises and innovations, and the share of this type of support was higher than in the regions included in the Convergence objective. In the Convergence objective regions, large amounts were spent on transport. Projects implemented under the Competitiveness objective mainly focused on supporting economic objectives, whereas those under the Convergence objective - in the field of social and sustainability objectives. ${ }^{37}$

In addition to transport investments, a significant importance is also given to environmental expenditures - about $12 \%$ of these outlays from 2 funds, EUR 6.7 billion in Poland. ${ }^{38}$ In the Republic, 18\% of funds were allocated to the environment, with more than half directed to water supply and wastewater treatment. ${ }^{39}$

Significant expenditures were also made on the support for enterprises and innovations, $20 \%$ of the ERDF and CF allocations, a higher share than for the EU-12. The effects of support are visible - 1,382 RTD projects, cooperation projects between enterprises and research institutions - 1057, 1993 projects in the field of start-up support, investment projects in SMEs $(14,955)$. Support was given primarily to the projects located in regions with a large number of enterprises in Poland. ${ }^{40}$ In the Czech Republic, the share of support directed at enterprises and innovations was similar, representing $19 \%$ of the funds from these two funds, with approximately $81 \%$ of the funds allocated to support innovation and RTD. Therefore, 1,423 RTD projects were supported, and the

\footnotetext{
35 Tasks 3. Country Report Czech Republic..., op. cit., pp. 11-12.

36 Tasks 3. Country Report Poland..., op. cit., pp. 12-13.

37 Tasks 3. Country Report Czech Republic..., op. cit., pp. 12-13.

38 Tasks 3. Country Report Poland..., op. cit., p. 20.

39 Tasks 3. Country Report Czech Republic..., op. cit., p. 19.

40 Tasks 3. Country Report Poland..., op. cit., p. 16.
} 
number of projects based on the cooperation between enterprises and research institutes amounted to $636 .{ }^{41}$

As shown by the considerations above, EU funds play an important role, considering the amount of investment outlays made thanks to those financial resources. However, in the new programming period more attention was paid to improving the efficiency of fund spending and better targeting thereof.

Table 5. Distribution of ERDF and CF in Poland and the Czech Republic in the 2007-2013 financial perspective in EUR million and \% (as of April 2016)

\begin{tabular}{|c|c|c|c|c|}
\hline \multirow[b]{2}{*}{ Category } & \multicolumn{2}{|c|}{ Poland } & \multicolumn{2}{|c|}{ Czech Republic } \\
\hline & million EUR & $\%$ of total & $\begin{array}{l}\text { million } \\
\text { EUR }\end{array}$ & $\%$ of total \\
\hline $\begin{array}{l}\text { 1. Innovation } \\
\text { \& RTD }\end{array}$ & $8,824.4$ & 15.4 & $3,395.5$ & 15.3 \\
\hline 2. Entrepreneurship & $1,072.7$ & 1.9 & 285.8 & 1.3 \\
\hline $\begin{array}{l}\text { 3. Other investment } \\
\text { in enterprise }\end{array}$ & $1,781.3$ & 3.1 & 502.9 & 2.3 \\
\hline $\begin{array}{l}\text { 4. ICT for citizens } \\
\text { \& business } \\
\end{array}$ & $2,656.0$ & 4.6 & 848.1 & 3.8 \\
\hline 5. Environment & $6,724.7$ & 11.8 & $3,925.9$ & 17.7 \\
\hline 6. Energy & $2,336.0$ & 4.1 & $1,316.5$ & 5.9 \\
\hline 7. Broadband & 940.2 & 1.6 & 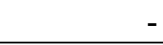 & - \\
\hline 8. Road & $15,910.6$ & 27.8 & $3,796.9$ & 17.1 \\
\hline 9. Rail & $5,479.1$ & 9.6 & $2,900.9$ & 13.1 \\
\hline 10. Other transport & $4,268.5$ & 7.5 & $1,085.7$ & 4.9 \\
\hline 11. Human capital & -1 & - & 110.6 & 0.5 \\
\hline 12. Labour market & - & - & 41.6 & 0.2 \\
\hline $\begin{array}{l}\text { 13. Culture \& social } \\
\text { infrastructure }\end{array}$ & $3,751.9$ & 6.6 & $1,808.6$ & 8.2 \\
\hline 14. Social inclusion & - & - & 3.4 & 0.0 \\
\hline $\begin{array}{l}\text { 15. Territorial } \\
\text { Dimension } \\
\end{array}$ & $1,863.6$ & 3.3 & $1,483.8$ & 6.7 \\
\hline 16. Capacity Building & 16.2 & 0.0 & 99.5 & 0.4 \\
\hline $\begin{array}{l}\text { 17. Technical Assist- } \\
\text { ance }\end{array}$ & $1,553.0$ & 2.7 & 540.5 & 2.4 \\
\hline Total & $57,178.2$ & 100.0 & $22,146.0$ & 100.0 \\
\hline
\end{tabular}

Source: own compilation based on: Tasks 3. Country Report Poland..., op. cit., p. 13; Tasks 3. Country Report Czech Republic..., op. cit., p. 12.

${ }^{41}$ Tasks 3. Country Report Czech Republic..., op. cit., p. 16. 


\section{Support of the Socio-economic Development in Poland and in the Czech Republic in the Years 2014-2020}

The priorities of the Czech Republic in the field of using funds under cohesion policy 2014-2020 are presented in the document: National Development Priorities (2014-2020), and becoming the main sources of funding the regional development in this country. Strategic objectives mostly include the support of business and innovation development and the instruments focus on the development of transport and business, innovation and environmental sustainability. The policy related to urban areas focuses on the sustainability, direct support of SMEs and the development of transport infrastructure, treating them as elements of regional development policy (included in the Principles of Urban Policy - 2010), whereas the strategic objectives related to the development of rural areas concentrates on sustainability and resilience. ${ }^{42}$

Changes have been implemented to the policy concerning the abovementioned areas for the years 2014-2020 in relation to the improvement of the potential of levels lower than the governmental one, and the use of instruments increasing and improving the use of structural funds, including ICT technology; by introducing tools such as Integrated Territorial Investments, Integrated Plans for Territorial Development, CommunityLed local Development better adjusted to the needs of the specific territories; the aim of the last instrument is to support the needs of local rural communities. ${ }^{43}$

In the 2014-2020 perspective, the directions of the regional policy in Poland are provided for by The National Strategy of Regional Development 2010-2020: Regions, Cities, Rural Areas (NSRD), supported by 16 regional development strategies for individual voivodeships. They also include the issues regarding the development of rural areas. However, The National Urban Policy 2023 was implemented in the field of urban policy in 2015. As far as the NSRD is concerned, it focuses on the competitiveness, support of territorial cohesion, prevention of the marginalisation of problem areas, and provision of appropriate instruments for certain territories ${ }^{44}$ Changes in the new financial perspective refer to those of administration and ministerial nature, the publication of the above-mentioned National Urban Policy 2023 for the sustainable development of cities and

${ }^{42}$ Country notes: Czech Republic, OECD Regional Outlook 2016: Productive Regions for Inclusive Societies, OECD 2016, http://www.oecd.org/cfe/regional-policy/regionaloutlook-2016-czech-republic.pdf (27.09.2018).

${ }^{43}$ Country notes: Czech Republic, OECD Regional Outlook 2016..., op. cit.

44 Country notes: Poland..., op. cit. 
functional areas as well as the Act on urban revitalisation and the Rural Development Programme 2014-2020.45

The funds allocated to the Czech Republic for the years 2014-2020 amounted to EUR 24.2 billion under the European structural and investment funds (ESIF) i.e. under the European Regional Development Fund, the European Social Fund, the Cohesion Fund, the European Agricultural Fund for Rural Development, the European Maritime and Fisheries Fund, and the Youth Employment Initiative. The funds have been provided under 11 programmes; the total allocations made along with the national funding amounted to EUR 32.08 billion. On the other hand, under the EU cohesion policy, the allocation for this country amounted to EUR 22 billion, of which EUR 15.3 billion was directed to less developed regions, and EUR 88 million to more developed regions, i.e. those with GDP per capita greater or equal to $90 \%$ EU GDP per capita - only for Prague, and 6.3 billion euro under the Cohesion Fund. EUR 340 million was allocated to European territorial cooperation objective and 13.6 million to the Youth Employment Initiative (YEI). As far as the distribution of EU funds is concerned, the largest amount was allocated under the ERDF, i.e. EUR 12.16 billion, and then under the Cohesion Fund - EUR 6.26 billion, and under the European Social Fund - EUR 3.43 billion. ${ }^{46}$ The Partnership Agreement indicates strategic objectives which are to be reached through the funds implemented, stating that "developing a high-quality business environment that will support the competitiveness of the Czech Republic in the European and global markets, will lead to the creation of new businesses, will enhance the innovative ability of existing business and will increase the attractiveness of the Czech Republic for domestic and foreign investors; providing of an inclusive society creating conditions for full assertion of all population groups, increasing the employment rate with an emphasis on reduction of the number of excluded population groups and supporting good living conditions for the population". ${ }^{47}$

45 Ibidem.

46 European Structural and Investment Funds: Country factsheet - Czech Republic, European Commission, April 2016, http://ec.europa.eu/regional_policy/sources/ policy/what/investment-policy/esif-country-factsheet/esi_funds_country_factsheet_cz_en.pdf (19.10.2018); Cohesion policy and the Czech Republic, October 2014, European Commission, http://ec.europa.eu/regional_policy/sources/information/cohesion-policy-achievement-and-future-investment/factsheet/czech_republic_en.pdf (19.10.2018).

47 Partnership Agreement for the Programming Period 2014-2020, Czech Republic, Ministry of Regional Development, 13 April 2016, p. 119, http://www.dotaceeu.cz/ getmedia/4589b39c-4215-4f0b-914d-b296678db1c8/Partnership-agreement-technical-revision-approved-by-the-EC-on-13-April-2016.pdf?ext $=$.pdf $(19.10 .2018)$. 
The amount of funds allocated to the Czech Republic and Poland under the European structural and investment funds in the years 2014-2020 are presented in Fig. 4 and Fig. 5.

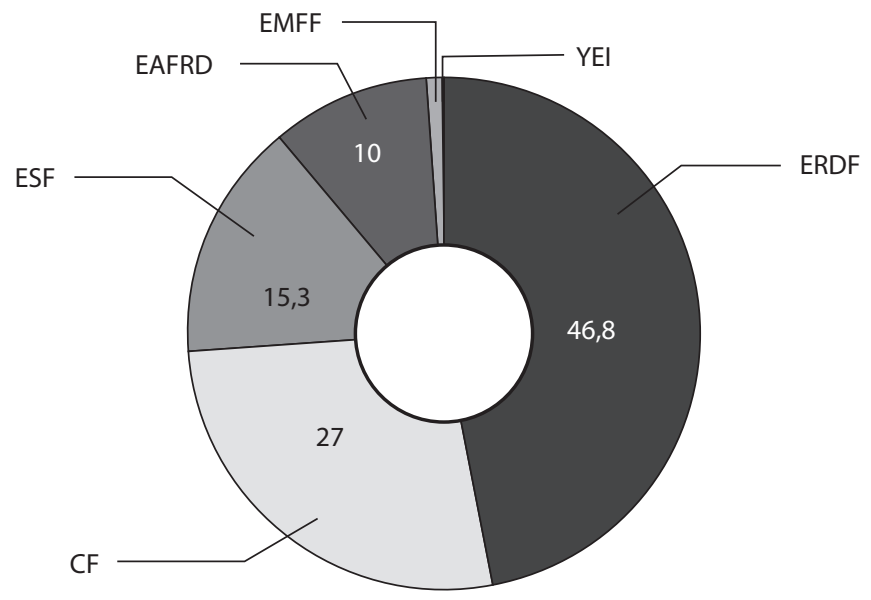

Fig. 4. Funds allocated to Poland under the European structural and investment funds in the years 2014-2020 (percentages)

Source: European Structural and Investment Funds: Country factsheet - Poland, European Commission, 19.05.2016, http://ec.europa.eu/regional_policy/sources/policy/what/ investment-policy/esif-country-factsheet/esi_funds_country_factsheet_pl_en.pdf (27.09.2018).

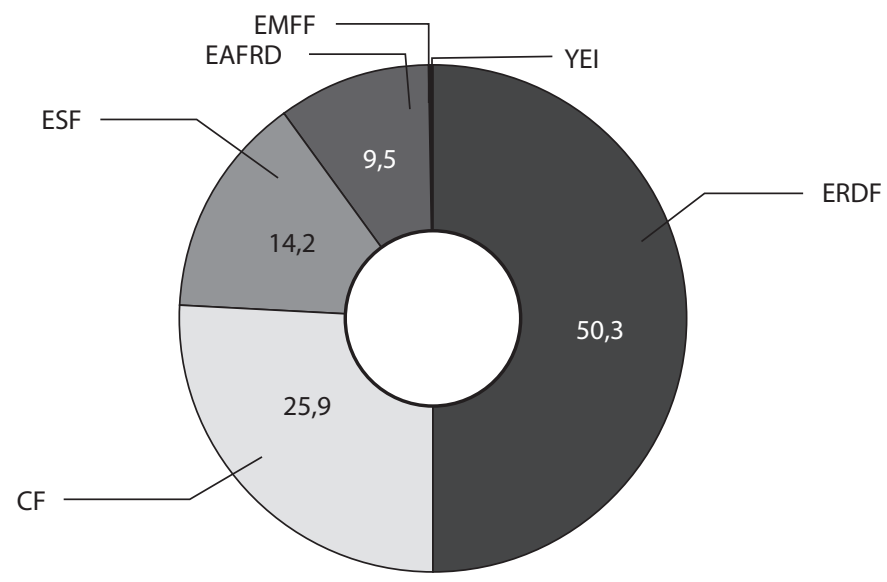

Fig. 5. Funds allocated to the Czech Republic under the European structural and investment funds in the years 2014-2020 (percentages)

Source: European Structural and Investment Funds: Country factsheet - Czech Republic..., op. cit. 
In the case of Poland, the allocations made under the European structural and investment funds in the years 2014-2020 amounted to EUR 86 billion, implemented through 24 programmes, without taking into consideration funds allocated as part of the national contribution in the amount of EUR 18.8 billion. As far as the directions of spending funds of EU cohesion policy are concerned, the largest allocation, i.e. EUR 40.21 billion, representing $46.8 \%$ of the funds, was made under the ERDF, EUR 23.2 billion under the Cohesion Fund (representing 27\%) EUR 13.19 billion under the ESF (representing 15.3\%), and EUR 252 million for the YEI. ${ }^{48}$ In the Partnership Agreement, which serves as a framework for the implementation of three policies, the financial means focus on the following priorities "entrepreneurship and innovation-friendly business environment; social cohesion and labour market participation; network infrastructure for growth and jobs; environment and effective source management". ${ }^{49}$

\section{Conclusion}

To sum up, it should be noted that Poland and the Czech Republic have become important beneficiaries of EU aid. In both countries, EU funds play a significant role, considering their share in total public expenditures. They have also contributed to positive socio-economic changes in these. countries. However, due to the scale of problems existing there and the amount of available funds, the directions of the use of such aid are varied. This is also affected by the regional policy implemented in each country. The results of the evaluation of programmes for the years 2007-2013 show that funds are mostly spent on transport infrastructure. However, the support of entrepreneurship and innovation and human capital should be an important objective in the current programming perspective in order to transform and modernise the structure of economies of both countries.

\section{References}

Cohesion policy and the Czech Republic, October 2014, European Commission,http://ec.europa.eu/regional_policy/sources/information/cohesion-policy-achievement-and-future-investment/factsheet/ czech_republic_en.pdf.

48 European Structural and Investment Funds: Country factsheet - Poland..., op. cit.

49 Programming of the 2014-2020 financial perspective - Partnership Agreement, 23 May 2014, Ministry of Infrastructure and Development, p. 9, https://www.poir. gov.pl/media/9498/Partnership_Agreement.pdf(19.10.2018). 
Country notes: Czech Republic, OECD Regional Outlook 2016: Productive Regions for Inclusive Societies, OECD 2016, http://www.oecd.org/cfe/ regional-policy/regional-outlook-2016-czech-republic.pdf.

Country notes: Poland, OECD Regional Outlook 2016, https://www.oecd. org/cfe/regional-policy/regional-outlook-2016-poland.pdf.

European Cohesion policy in the Czech Republic, European Union, http:// ec.europa.eu/regional_policy/sources/docgener/informat/country2009/ cs_en.pdf.

European Cohesion policy in Poland, European Union, http://ec.europa.eu/ regional_policy/sources/docgener/informat/country2009/pl_en.pdf.

European Structural and Investment Funds: Country factsheet - Czech Republic, European Commission, April 2016, http://ec.europa.eu/regional policy/sources/policy/what/investment-policy/esif-country-factsheet/ esi_funds_country_factsheet_cz_en.pdf.

Eurostat news release 33/2018, 28 February 2018, Regional GDP per capita ranged from $29 \%$ to $611 \%$ of the EU average in 2016, https://ec.europa.eu/ eurostat/documents/2995521/8700651/1-28022018-BP-EN/15f5fd90ce8b-4927-9a3b-07dc255dc42a.

Gorzelak G., Fakty i mity rozwoju regionalnego (Facts and Myths of Regional Development), „Studia Regionalne i Lokalne”, no. 2(36)/2009.

Gorzelak G., Wykorzystanie środków Unii Europejskiej dla rozwoju kraju-wstępne analizy (Utilisation of EU financial resources for the development of country preliminary analyses), „Studia Regionalne i Lokalne”, no. 3(57)/2014.

https://ec.europa.eu/eurostat/data/database.

Jak państwa UE-15 korzystaja z realizacji polityki spójności w krajach Grupy Wyszehradzkiej? Raport końcowy z badania pt. Ewaluacja ex post i prognoza korzyści uzyskiwanych przez państwa UE-15 w wyniku realizacji polityki spójności w krajach Grupy Wyszehradzkiej (How do EU-15 Member States benefit from the cohesion policy in the V4? Final report from the evaluation: Ex-post evaluation and forecasts of benefits to EU-15 countries as a result of cohesion policy implementation in the V4), IMAPP sp. z o.o., IBS, Warszawa 2017.

Kudełko J., Prusek A., Zieliński K., Europejska polityka spójności oraz jej efekty $w$ Polsce (European cohesion policy and its effects in Poland), Wydawnictwo Uniwersytetu Ekonomicznego w Krakowie, Krakowie, Kraków 2011.

Murzyn D., Polityka spójności Unii Europejskiej a proces zmniejszania dysproporcji w rozwoju gospodarczym Polski (EU cohesion policy and the proces in the economic development of Poland), Wydawnictwo C.H. Beck, Warszawa 2010.

Ocena korzyści uzyskiwanych przez Państw UE-15 w wyniku realizacji polityki spójności w Polsce. Raport końcowy (Evaluation of benefits gained by 
$E U-15$ as a result of the implementation of cohesion policy in Poland. Final report), Instytut Badań Strukturalnych 2017.

OECD Economic Surveys: Poland 2018, OECD Publishing, Paris 2018, http://dx.doi.org/10.1787/eco_surveys-pol-2018-en.

OECD Economy Surveys: Czech Republic 2018, OECD Publishing, Paris, https://doi.org/10.1787/eco_surveys-cze-2018-en.

Partnership Agreement for the Programming Period 2014-2020, Czech Republic, Ministry of Regional Development, 13 April 2016, http:// www.dotaceeu.cz/getmedia/4589b39c-4215-4f0b-914d-b296678db1c8/ Partnership-agreement-technical-revision-approved-by-the-EC-on-13 -April-2016.pdf?ext $=$.pdf.

Polityka spójności w okresie 2014-2020 a rozwój regionów Europy (Cohesion policy in 2014-2020 and development of regions of Europe), eds. E. PancerCybulska, E. Szostak, Prace Naukowe Uniwersytetu Ekonomicznego we Wrocławiu, no. 227, Wrocław 2011.

Potluka O., Brůha J., EU cohesion policy attribution to employment; a case of the Czech Republic, https://ecpr.eu/Filestore/PaperProposal/e13a36964251-4f98-8800-d72e79c343ba.pdf.

Programming of the 2014-2020 financial perspective - Partnership Agreement, 23 May 2014, Ministry of Infrastructure and Development, https:// www.poir.gov.pl/media/9498/Partnership Agreement.pdf.

Regions and cities at a glance 2018 - Czech Republic, OECD, http://www. oecd.org/cfe/CZECH-REPUBLIC-Regions-and-Cities-2018.pdf.

Regions and cities at a glance 2018 - Poland, OECD, http://www.oecd.org/ cfe/POLAND-Regions-and-Cities-2018.pdf.

Smékalová L., Janiček P., Škarka M., Kozák V., Spatial concentration of the cohesion policy projects nationally delimitated intervention areas: the case of the Czech Republic and Poland, "Economics and Sociology", vol. 8, no. 2/2015.

Tasks 3. Country Report Czech Republic, ex post evaluation of Cohesion Policy programmes 2007-2013, focusing on the European Regional Development Fund (ERDF) and the Cohesion Fund (CF), WP1: Synthesis report, Applica, Ismeri Europa and Cambridge Economic Associates, Publications Office of the European Union, Luxembourg 2016.

Tasks 3. Country Report Poland, ex post evaluation of Cohesion Policy programmes 2007-2013, focusing on the European Regional Development Fund $(E R D F)$ and the Cohesion Fund (CF), WP1: Synthesis report, Applica, Ismeri Europa and Cambridge Economic Associates, Publications Office of the European Union, Luxembourg 2016.

The impact of cohesion policy 2007-2013: in Poland, Visegrad Group Countries and partner states, Imapp, Warsaw 2017. 